\title{
Japan's New ASEAN Diplomacy: Strategic Goals, Patterns, and Potential Limitations under the Abe Administration
}

\author{
Mahar Nirmala
}

\begin{abstract}
This paper examines the strategic goals of Japan's New ASEAN Diplomacy introduced by Prime Minister Abe Shinzo in 2013 and analyzes the patterns and potential limitations for Japan. This paper suggests that Japan's engagement in Southeast Asia is intended to maintain the status quo of the South China Sea, to contain China's perceived threat, and to create a stable region in which Japan can exert greater influence and take full advantage in the future. In order to support this analysis, I provide an explanation regarding what has been done by Japan by categorizing ten ASEAN countries into three different groups to find the patterns of the engagement. It is found that Japan has a different strategy and priority for different countries, particularly in the focus and intensity of the cooperation. These findings supported the arguments of Japan's strategic goals mentioned above. The last section of this paper criticizes Abe's engagement policy by presenting several potential limitations for Japan, including different perception regarding China's threat, suspicion from the ASEAN countries that Japan may undermine the ASEAN principles, and relatively minor contribution from those who are regarded as small states to maintain the maritime security.
\end{abstract}

Index Terms-Abe Shinzo, ASEAN diplomacy, Japan, Southeast Asia.

\section{INTRODUCTION}

In 2013 Japanese Prime Minister Abe Shinzo has completed his visits to ten Southeast Asian countries only within the first year of his administration. Abe was the first Prime Minister to visit all of the ASEAN (Association of Southeast Asian Nations) countries, which illustrates the importance of this region for Japan. During his visit to Jakarta in January 2013, Abe unveiled the five principles of Japan's New ASEAN diplomacy. Firstly, to establish and expand universal values such as freedom, democracy, and basic human rights. Secondly, to protect the free and open seas as common goods, which are governed by laws and rules, and to welcome the United States' rebalancing to the Asia-Pacific. Thirdly, to further promote flows of trade and investment. Fourthly, to protect and nurture Asia's diverse cultures. Fifthly, to actively promote exchanges among younger generations [1].

These guiding principles signify that Japan's engagement in Southeast Asia has entered a new policy agenda. Among these principles, it is worth to note that Japan considered

Manuscript received February 11, 2016; revised April 23, 2016. This work was supported by the Indonesia Endowment Fund for Education.

M. Nirmala is with the Graduate School of International Studies, Seoul National University, South Korea (e-mail: nirmala@snu.ac.kr). maritime security as one of the main agendas in the region. In the preamble of his speech Abe also mentioned that Japan's national interest lies in keeping Asia's seas unequivocally open, free, and peaceful. Following this principle, Japan proactively engages in several joint military exercises and training with Southeast Asian countries and provides them with financial and technical assistance. Japan's foreign policy toward Southeast Asia could be addressed as shifting from the economic-social approach to the political-security approach. This paper explores the strategic goals of the Abe's diplomacy in Southeast Asia and examines the new patterns and the potential limitations of this policy.

\section{JAPAN's STRATEGIC GOALS IN SOUTHEAST ASIA}

Japan's engagement in Southeast Asia under the Abe administration has entered a new policy agenda and has shifted from the economic-social approach to the politicalsecurity approach. Abe's move in Southeast Asia is more decisive than his predecessor, Prime Minister Noda Yoshihiko, even though we cannot deny his important role in initiating the cooperation with several Southeast Asian countries during his administration. In regards to the Abe's strong commitment to undertake strategic engagement in Southeast Asia, many literatures suggest that extensive arguments on the reasons behind Japan's engagement exist. In this paper, I provide three strategic goals for Japan's engagement in Southeast Asia and elaborate the supporting arguments offered by several experts.

The first goal of Japan's strategic engagement in Southeast Asia is to maintain the status quo of the South China Sea, a sea that serves Japan's economic and security interests, in which at the same time is being under dispute between several Southeast Asian countries and China. China's claim on the nine-dash area is certainly overlapping with the claim of Brunei, Malaysia, the Philippines, and Vietnam in the Spratly Island and the claim of Vietnam in the Paracels [2]. Furthermore, China's assertive behavior has threatened these relatively small countries that mostly lack on the military capabilities and security framework. In regard to this fact, Japan intends to prevent any unilateral actions that may change the status quo of the South China Sea by supporting Southeast Asian countries' security capacity building and insisting countries in the region to cooperate and adhere to the principles of the United Nations Convention on the Law of the Sea (UNCLOS).

There are several advocates that support the argument of preserving the status quo of the South China Sea. First, Ken 
Jimbo, a senior fellow for the Tokyo Foundation as well as an expert of the Japan's foreign and security policy, argues that preserving the stability of the South China Sea has become a renewed policy agenda for Japan's proactive engagement in Southeast Asia. One of Japan's interests in this matter is to ensure that the rules and mechanisms for maritime security are consolidated. However, the current standoff that shows China's growing maritime capability vis-à-vis ASEAN's relatively slow progress in establishing maritime orders have endangered Japan's interest to preserve the status quo of the South China Sea. Therefore, Japan is committed to help Southeast Asian countries build their security capacity by actively engaging them in joint military exercises and training and boosting the amount of the Official Development Assistance (ODA) to those countries [3].

Another expert of Japan's foreign and security policies and maritime security, Hornung Jeffrey, argues that there is no country in the world that can secure its peace and security by itself, including Japan. In this case, Japan needs to cooperate with Southeast Asian countries to secure its interest in the South China Sea. In order to build a unified backing of Japan's interpretation of the UNCLOS, Japan has supported the capacity building of Southeast Asian countries by conducting joint military training and providing hightech equipment and patrol boats to several countries [4].

Pajon Céline, a researcher of Japan's foreign and defense policy from the French Institute of International Relations, offers a similar argument with Hornung. Pajon explains that Japan's proactive engagement in Southeast Asia is driven by the idea that the South China Sea is a matter of survival for Japan, thus Japan needs to build Southeast Asian countries' security capacity to defend themselves and to form a "maritime countries union." This network of the likeminded security partners is important for Japan to face China's growing military capability and assertive actions. In order to achieve this goal, Japan utilizes its ODA as an instrument to build this network [5].

Correspond to Ken and Pajon's argument regarding the use of ODA, Przystup James, senior research fellow in the Center for the Strategic Research at the National Defense University, and Tatsumi Yuki, senior associate of the East Asia Program at the Stimson Center, argue that Japan has made a strategic use of ODA in order to build law enforcement capacities in the maritime domain across Southeast Asia. In addition, Abe also strengthens both the regional multilateral security framework, including ASEAN and East Asia Summit (EAS), and the individual ASEAN member countries to maintain the status quo of the South China Sea [6].

Lastly, Shiraishi Takashi, President of the National Graduate Institute for Policy Studies (GRIPS), argues that Japan's proactive engagement in Southeast Asia is intended to invite all the countries in the region to participate in the process of drawing up the rules, particularly the rules of the seas, based on the legal principles and international laws. More importantly, Japan's engagement in Southeast Asia is also intended to encourage all the countries to abide by the rules that have been formulated. Regarding this intention, Japan considers ASEAN countries as one of the important actors to work with to build an order for the Asia-Pacific region [7].

The second strategic goal of Japan's engagement in Southeast Asia is to contain China's aggressive and assertive actions. Even though this argument might be seen as an exaggeration of Japan's threat perception toward China, this idea is quite popular in the Japan-China relation's discourse. There are several experts that support this argument. First, Trinidad Dennis, argues that Japan is pursuing a soft containment strategy toward China to allow both engagement and curtailment of China's influence in the region. Even though this strategy is not purely intended to contain China, it helps Japan mitigating China's charm offensive. In order to achieve this goal, Japan utilizes value diplomacy and institution building to strengthen its ties with Southeast Asian countries. This kind of diplomacy refers to the use of democracy, human right, and international law - a set of values that China is lacking - to soften Japan's diplomacy [8].

Another advocate, Lu Yaodong, director of the Department of Japanese Diplomacy at the Institute of Japanese Studies of the Chinese Academy of Social Sciences, also argues that the objective of the Abe's diplomatic strategy and frequent visit in Southeast Asia is primarily to build a maritime alliance with the corresponding countries in order to contain China. Lu shares similar argument with Trinidad, mentioning that Japan tries to counter China by promoting value-oriented diplomacy and pouring large-sum investment and debt-relief programs. Furthermore, Lu argues that Japan is trying to isolate China by playing up the South China Sea dispute and forcing the non-contending parties to take sides [9].

Different from the other Japanese analysts, Shimada Yoichi, a professor of international relations at Fukui Prefectural University, offers a bold argument regarding Abe's pledge to provide financial assistance for the Mekong countries, which include Cambodia, Laos, Myanmar, Vietnam, and Thailand. He argues that Abe's priority of giving financial assistance to those countries is to find effective ways to counter China's aggressive and assertive actions instead of ensuring the peace and stability in the Mekong region, a strategic point that serves Japan's economic interest. Shimada further argues that the Japanese government would hesitate to admit that this move is intended to counter China, even though this is true [10].

The last strategic goal of Japan's engagement in Southeast Asia is to create a stable region that will benefit Japan in the future, as well as to allow Japan exerting greater influence in the region. Aizawa Nobuhiro, associate professor at the Graduate School of Social and Cultural Studies at Kyushu University, argues that Japan has four strategic goals in Southeast Asia. First, to build a stronger Southeast Asia in order to create a stable and prosperous region both for its own well being and for stronger Asia generally. Second, to gain legitimacy from Southeast Asian countries. Third, to take full advantage of the great talent and youth in the region while Japan is facing demographic challenges of an aging society. Fourth, to redefine Japan's role in Southeast Asia since Japan is no longer an economic giant and a military powerhouse [11]. However, these goals are loosely defined and do not explain Japan's immediate needs. 


\section{The PATterns OF JAPAN'S StRATEGiC ENGAGEMENT IN SOUTHEAST ASIA}

Regarding Japan's engagement strategy in Southeast Asia, Abe seems to put priority and implements different strategy on his partnership. For the purpose of focusing the discussion and examining the pattern of the relations between Japan and each country, I categorize ten Southeast Asian countries into three different groups. The explanation of the pattern of the engagement is intended to support the argument of Japan's strategic goals analyzed in the previous section.

The first group consists of the main partner countries, including Indonesia, the Philippines, and Vietnam. These countries have been regarded as the main partners for Japan in Southeast Asia. Vietnam and Indonesia are two of the first destinations of Abe's tour in Southeast Asia. Abe defined the relations with Vietnam as an "Extensive Strategic Partnership" and he has also designated Indonesia as a strategic partner for Japan since 2006. In the case of the Philippines, together with Indonesia, both countries are archipelagic states whose stability depends on a stable maritime environment. Vietnam also has a long coastline facing the South China Sea, thus Vietnam needs to secure the maritime environment to support its marine-base economic activities [12].

The second group consists of Brunei Darussalam, Malaysia, Singapore, and Thailand. These countries can be regarded as pro-America rather than pro-China. In his Southeast Asia tour in 2013, Abe decided to visit Thailand in January, Singapore and Malaysia in July, and Brunei Darussalam in October, at the same time when the ASEANrelated Summit Meeting was held in Bandar Seri Begawan. Besides their political tendency that are closer to the United States rather than to China, Japan considers these countries as important partners because Singapore, Malaysia, and Brunei Darussalam are also involved in the South China Sea dispute. Therefore, by engaging these countries, Japan can restrain China's move to solve the dispute bilaterally.

The last group consists of the mainland countries, including Cambodia, Laos, and Myanmar. These countries are known to have good relations with China both politically and economically. On the series of his visit to Southeast Asia, Abe decided to visit Myanmar in May 2013. He was the first Japanese leader to visit Myanmar in thirty-six years. For Cambodia and Laos, Abe saved those countries for the last, in November 2013. Instead of focusing on the negative image of being the last destinations, this visit shows that Abe wants to embrace these countries and cooperate with them, particularly in the case of the South China Sea, even though these countries are not involved in the dispute. Japan needs their support, at least for not taking sides with China in the dispute.

The following Fig. 1 summarizes Japan's engagement framework in Southeast Asia. This categorization is based on the Japanese consideration regarding its strategic partners in Southeast Asia. However, it is not an absolute categorization and is only used to examine the pattern of engagement with each country in different group.

The first group countries are considered to be the main partners for Japan, particularly to call for the rule of law and freedom of navigation in the South China Sea. As for
Indonesia, Japan expected a great role from this country to seek peace and stability in the region since Indonesia is the center of ASEAN. Japan and Indonesia became a "strategic partners" since November 2006 when the leaders of both countries agreed on "Strategic Partnership for Peaceful and Prosperous Future." Nine years later, the two countries agreed to strengthen the strategic partnership underpinned by sea and democracy in March 2015. As part of their joint statement, Japan and Indonesia concurred in establishing Japan-Indonesia Maritime Forum in the near future to accelerate their maritime cooperation. To date, Japan has been building Indonesia's human resource development and providing patrol vessels to preserve the Strait of Malacca. The cooperation between the two countries has been advanced when both leaders welcomed the signing of the Memorandum between the Ministry of Defense on Cooperation and Exchanges in the field of defense and reaffirmed their commitment to hold the "Joint Foreign and Defense Ministerial Consultation."

As for the Philippines, Japan and the Philippines became a "strategic partners" since 2011. In April 2015, the Japan Marine United Corp won a bid to supply the Philippine with ten multirole response vessels, a provision that cost around \$168 million, which will be delivered from 2016-2018. Following this pledge, both countries conducted their first joint naval exercises in the South China Sea in May 2015. Their relationship is going deeper when both leaders signed the Joint Declaration on the "Strengthened Strategic Partnership" in June 2015, which signifies the exploration on the transfer of Japanese military hardware and technology and discussions on a visiting force agreement. Following up this Joint Declaration, both countries agreed on a pact for transfer of defense equipment and technology in November 2015. Japan is also considering offering secondhand TC-90-twin-engine turboprop aircraft to the Philippines for the purpose to patrol over the South China Sea [13].

Besides the Philippines, Japan also builds a firm partnership with Vietnam. Japan and Vietnam have become a "strategic partners" since 2006 and both countries endorsed the Memorandum of Understanding on Defense Cooperation in October 2011. In 2014 Japan promised to provide six vessels to Vietnam worth of \$4 million and have been delivered in 2015. In September 2015, Prime Minister Abe Shinzo and General Secretary Nguyen Phu Trong agreed on the "Joint Vision Statement on Japan-Vietnam Relations" as well as on the "Memorandum on Cooperation between Coast Guard Agencies." In the Joint Vision Statement, Japan promised to continue its assistance to Vietnam in order to enhance the capacity of maritime law enforcement, while in the latter memorandum, Japan pledged to provide $\$ 1.66$ billion aid grants. In early November this year, both countries agreed to allow Japan's Maritime Self Defense Force (MSDF) to make port calls in Cam Ranh Bay. Both parties are also discussing the possibility of joint naval exercise in the near future [14].

For the second group countries, Japan is also strengthening its relations with Brunei Darussalam, Malaysia, Singapore, and Thailand. In the case of Brunei, Prime Minister Abe and Sultan Hassanal Bolkiah agreed to enhance their bilateral relation in the fields of energy, 
economy, and defense in 2013. Even though Japan-Brunei relations is not exclusively related to the security and defense area, both countries agreed to further their cooperation at the time of their $30^{\text {th }}$ anniversary of diplomatic relations in 2014. In 2013, when Brunei chaired the ASEAN, this country has been vocal in establishing a Code of Conduct on the South China Sea, a move that certainly helps Japan to keep China in check following China's assertive behaviors in this issue.

As for Malaysia, Japan and Malaysia enhanced their relations to a "strategic partnership" in May 2015 after their relations remain at the stage of "enhanced partnership" since 2010. As a strategic partner, both countries agreed to begin the discussion on transfer of defense equipment and technology, with the focus on the disaster relief and maritime security, amidst the growing concerns about China's assertive behaviors in the South China Sea. It seems that the maritime security has become the only specific issue in this document and suggests that Japan could increase Malaysia's coast guard capacity building. To date, Japan has been helping Malaysia by providing capacity building for Malaysia's Maritime Enforcement Agency (MMEA) [15].

Besides Malaysia, Japan's engagements to Singapore have also been regarded as successful. Even though prior to 2010 their relations focused on the anti-piracy, it increasingly has come to focus on the maritime security issues. It cannot be denied that Singapore is more welcoming the United States than Japan in providing security and military assistance. However, Singapore is still expressing hope for Japan's leadership to address the problem of the South China Sea. During the JapanSingapore Summit Meeting in November 2015, Prime Minister Lee Hsien Loong stated that he supports the idea of resolving the maritime dispute peacefully by conforming to the international law and confirms the importance of freedom of navigation on the high seas [16].

As for Thailand, Japan's relation with this country dates back in May 1998 when both countries agreed to hold a Politico Military Talks once every year to strengthen their cooperation in the security area. In March 2012, Prime Minister Shinawatra Yingluck and Prime Minister Noda Yoshihiko agreed to establish a "strategic partnership" based on the "Enduring Bonds of Friendship - Fostering Confidence beyond the Disasters," an agreement that signifies the importance of frequent visits and dialogues on political and security issues at every level, including the Japan-Thailand Political Partnership Consultations and Politico-Military (PM) and Military-Military (MM) Dialogues. In February 2015, both countries agreed to strengthen their relations on the occasion of the visit by Prime Minister Prayut Chan-o-cha. They also welcomed Japan Self-Defense Forces (JSDF)'s participation in the Cobra Gold Exercise, the largest joint military exercise in the Asia-Pacific.

Besides strengthening bilateral relations with the first and second group countries, Japan is starting to build closer relationships with Cambodia, Laos, and Myanmar, particularly through the Japan-Mekong Cooperation, together with Thailand and Vietnam. As for Cambodia, in 2013 Prime Minister Hun Sen proposed an upgrade of their bilateral relations from the "new partnership" that existed since 2007 to a "strategic partnership" to advance defense cooperation and exchanges. Since then, Japan-Cambodia relations evolve to support Cambodia's economy and domestic security. As part of Japan's "Proactive Contribution to Peace" policy, Japan intends to support electoral reforms in Cambodia and the Khmer Rouge Trial. Even though their strategic partnership was initially intended to strengthen their defense cooperation, Japan's assistances to Cambodia are mainly related to the economic development, poverty reduction, and governance issues.

As for Laos, Japan and Laos agreed on establishing strategic partnership in March 2015 to advance the "comprehensive partnership" that was signed in 2010, as the two countries are commemorating the $60^{\text {th }}$ anniversary of their diplomatic relations last year. On the security dimension, both countries agreed to devote the assistance on the issues related to Humanitarian Assistance and Disaster Relief (HADR), as well as to accept Lao students in the National Defense Academy of Japan and to assist counterterrorism [17]. However, although both countries already established strategic partnership, Japan's main agenda in the political and security area in Laos is still limited to promote universal values including freedom, democracy, and respect for human rights.

For the last country, Myanmar, Japan seems to put Myanmar's domestic security issue above the other agendas. On his visit to Myanmar in May 2013, Abe expressed his readiness to assist Myanmar's effort for democratization and to improve Myanmar's infrastructure development through the Official Development Assistance [18]. According to Watanabe Tsuneo, a senior fellow for the Tokyo Foundation, Myanmar's democratization initiative will have an impact on the future regional order. Therefore, Japan has devoted its resource to assist Myanmar and to collaborate with a domestic NGO in order to facilitate the process of ethnic reconciliation in Myanmar [19].

From the categorization provided above, several patterns regarding Japan's strategy and approach to every group can be addressed. For the first group, Japan's main partners in Southeast Asia, these countries had already established deep relationship with Japan in the security and defense area, which shows that Japan's engagement in the first group countries is intended to support Japan's effort to preserve the status quo of the South China Sea and to contain China's perceived threat. In this case, Indonesia and Vietnam had established "strategic partnership" with Japan in 2006 and advances their relations since then, particularly on the maritime security area. While the Philippines has just established a strategic partnership with Japan in 2011, both countries advances their security and defense cooperation at a fast pace. In this case, Japan's ODA plays a large role in the security capacity building, most notably in the Philippines and Vietnam. Japan utilized its ODA as a foreign policy tool to invite the like-minded partners to help ensure Japan's own security.

As for the second group, until recently Japan only has a strategic partnership agreement with Malaysia and Thailand, in which both are relatively new since they were established in 2015 and 2012 respectively. For Japan, Malaysia is being considered as an important partner to preserve the stability of Strait of Malacca, while Thailand is being considered as 
the gateway to ASEAN, in which as a mainland country Thailand is able to hold out from China's sphere of influence. As for Singapore, Japan-Singapore relation shows a positive sign following further cooperation in the security and defense cooperation. In the case of Brunei, Japan seems to prioritize the economic rather than the security and defense cooperation. This can be explained by the fact that Japan prefers to have a partnership on the energy sector with Brunei. However, the fact that Brunei, Malaysia, and Singapore also have territorial disputes with China shows an unconditional support for Japan to preserve the stability of the South China Sea and to restrain China from resolving the dispute bilaterally.

Different with the first and second group, Japan's main agenda in the last group is to promote internal security rather than to support Japan directly in the issue of the South China Sea. Japan's assistance towards Cambodia, Laos, and Myanmar is intended to minimize China's influence in these countries, as well as to create a stable condition and to exert greater influence, particularly by engaging them through the Japan-Mekong Cooperation. Last year during the Seventh Mekong-Japan Summit in Tokyo, Japan had pledged \$6.1 billion over the next three years to aid the Mekong countries This can be regarded as part of a bid for influence amid the rise of Asia Infrastructure Investment Bank (AIIB) proposed by China in 2013 [20].

Furthermore, it is interesting to note that Japan had already established strategic partnership with Cambodia and Laos in 2013 and 2015 respectively, which shows a good sign for broader security and defense cooperation in the future. It is also interesting to note that the countries in the third group show their desire to have further cooperation with Japan, especially with Cambodia's initiative to upgrade its relation with Japan to a "strategic partnership" in only six years after the establishment of a "new partnership" in 2007 and Myanmar's eagerness to gradually pull out itself from China's influence due to China's support to the military junta.

\section{Potential Limitations OF THE JAPAN'S NEW ASEAN DIPLOMACY}

Japan's strategic engagement in Southeast Asia is generally being regarded as a result of the recent trend of the United States' Rebalance to Asia-Pacific and China's Charm Offensive. Abe considers the need to engage Southeast Asian countries to prove that Japan is not declining and is "caring" to its neighbors amidst China's growing assertive behavior in the South China Sea dispute. Japan's interest to preserve the status quo of the South China Sea has led Abe to strengthen security and defense cooperation with Southeast Asian countries. Japan is proactively engaged all Southeast Asian countries bilaterally and regionally trough several regional institutions, including the ASEAN Regional Forum, the East Asia Summit, and the ASEAN Defense Ministers' Meeting Plus. However, Japan's New ASEAN Diplomacy may face several limitations on the implementation stage, which in the end can cause an adverse effect for Japan. There are at least three potential limitations that Japan may face as a result of the ASEAN member countries' reluctance to fully embrace Japan's vigorous engagement in Southeast Asia.

The first limitation is related to the fact that Japan and Southeast Asian countries do not perceive the same threat from China. Japan and China have long standing historical and territorial disputes, which sometimes aggravate their bilateral relations. In the case of Southeast Asian countries, only several countries are involved in the South China Sea dispute. The perception of China as a threat is strong only in the Philippines and Vietnam, the main partners of Japan in Southeast Asia. As for Indonesia, the former President Susilo Bambang Yudhoyono suggested that Japan's security role should be pursued gradually. For the rest of the ASEAN member countries, their main interest to cooperate with Japan is to prevent any domination from major power, including China and the United States, instead of fully welcoming Japan in the region or assuming China as their potential threat. Regarding the dispute on the South China Sea, the non-contending parties try to avoid taking any sides to maintain the balance of power in the region [21].

The second limitation is related to the ASEAN principles that respect the sovereignty, equality, territorial integrity, non-interference, consensus and unity in diversity. Japan's vigorous engagement in Southeast Asia that emphasized on the value-based diplomacy may undermine the principle of sovereignty and unity in diversity since each ASEAN member country has different political and economic characteristics. Furthermore, Japan's proactive engagement in the security and defense area to preserve the status quo of the South China Sea and to seek greater influence in the region may undermine the principle of consensus and noninterference, which in the end will weaken the ASEAN members' solidarity. It is also almost certain that even in ten years ahead Southeast Asian countries will not consider any military alliance with Japan due to their intention to keep the balance of power in the region and most of them still prefer the United States to Japan in the security area.

The last limitation is that Southeast Asia is comprised of small states in terms of their economic and defense capability, particularly for Cambodia, Laos, and Myanmar. Therefore, their contribution to regional security is relatively minor. It is obvious that small state has to engage with other countries and will not afford to limit itself from any foreign aid [22]. In the case of Cambodia, even though Japan's assistance to this country is deepening, Cambodia is also advancing its relation with China. The fact that Cambodia upgraded its relation with China to the level of strategic partnership in 2010, three years before upgrading its relation with Japan in 2013, shows that Cambodia still regards China as a close partner rather than as a source of threat. Furthermore, the mainland countries except Thailand are not involved in the South China Sea dispute, thus their interest in preserving the regional security is lower than those who are involved in the dispute.

\section{CONCLUSION}

Japan's diplomacy towards Southeast Asia under the Abe administration has entered a new policy agenda focusing on the political-security areas. In a sense, Japan's New ASEAN diplomacy has been regarded as the consequence of the United States' Rebalance to the Asia-Pacific region and 
China's Charm Offensive. With these recent engagement policies from two major powers, Japan considers the need to engage the ASEAN countries to maintain the status quo of the South China Sea that serves Japan's economic and security interest, to contain China's perceived threat, and to create a stable region in which Japan can exert greater influence and take full advantage in the future.

In order to achieve those goals, Japan has a different strategy and priority for different countries due to each country's unique political and socio-economic background. The difference lies in the focus and intensity of the cooperation to promote Southeast Asian countries' security capacity building. Japan puts more attention on the security issue and provide more military assistance to Indonesia, the Philippines, and Vietnam as these countries have been regarded as the main partners to call for the rule of law in the South China Sea. For the second group, Japan is in the phase of further engaging Malaysia, Singapore, and Thailand in the security and defense area, while focusing more on the economic partnership with Brunei. As for Cambodia, Laos, and Myanmar, Japan puts more effort to promote universal values and to ensure their internal security.

Apart from these vigorous engagements, Japan's New ASEAN Diplomacy is facing several potential limitations, including different perception regarding China's threat, suspicion from the ASEAN countries that Japan may undermine their basic principles, and relatively minor contribution from several Southeast Asian countries that are considered as small states to preserve the regional and maritime security. In the meantime, Japan needs to reconsider its engagement policy in Southeast Asia without exaggerating the China's threat factor, therefore Japan's role and influence in the region will not depend on whether China's influence is waxing or waning.

\section{REFERENCES}

[1] Cabinet Public Relations Office, Cabinet Secretariat. (January 18, 2013). The bounty of the open seas: five new principles for Japanese diplomacy. $\quad$ [Online]. Available: http://japan.kantei.go.jp/96_abe/statement/201301/18speech_e.html

[2] R. Emmers, "Maritime disputes in the South China sea: Strategic and diplomatic status quo," Maritime Security in Southeast Asia, New York: Routledge, 2007, pp. 49-52.

[3] J. Ken, "Japan-southeast Asia relations: Implication of US rebalance to the Asia-pacific region," in Japan's Foreign Policy Challenges in East Asia, Y. Tatsumi, Ed. Washington: Stimson, 2014, pp. 53-58.

[4] J. W. Hornung. Gauging Japan's 'proactive contributions to peace. [Online]. Available: http://thediplomat.com/2015/10/gauging-japansproactive-contributions-to-peace/

[5] C. Pajon. (December 2013). Japan's "smart" strategic engagement in Southeast Asia. [Online]. Available: http://www.theasanforum.org/japans-smart-strategic-engagement-insoutheast-asia/

[6] J. Przystup and Y. Tatsumi. (February 2015). The foreign policy of Abe Shinzo: strategic vision and policy implementation. [Online]. Available: http://www.theasanforum.org/the-foreign-policy-of-abeshinzo-strategic-vision-and-policy-implementation/

[7] T. Shiraishi. Abe's visit to Southeast Asia and Japan's five new diplomatic principles. [Online]. Available: http://www.nippon.com/en/editor/f00016/

[8] D. D. Trinidad. (September 2013). Abe's ASEAN tour. [Online]. Available: http://www.eastasiaforum.org/2013/09/06/abes-asean-tour/
[9] Y. Zhang. Containing China' a Japanese strategy. [Online]. Available: http://www.chinadailyasia.com/news/201312/12/content_15105387.html

[10] J. Ryall. Japan pledges billions to Mekong States to counter China [Online]. Available: http://www.dw.com/en/japan-pledges-billions-tomekong-states-to-counter-china/a-18570364

[11] N. Aizawa. (April 2014). Japan's strategy toward Southeast Asia and the Japan-U.S. alliance. Center for Strategic and International Studies [Online]. Available: http://csis.org/files/publication/140422_Aizawa_JapansStrategySouth eastAsia.pdf

[12] H. S. Nguyen, "ASEAN-Japan strategic partnership in southeast Asia: Maritime security and cooperation," in Beyond 2015: ASEAN-Japan Strategic Partnership for Democracy, Peace, and Prosperity in Southeast Asia, R. Sukma and S. Yoshihide, Ed. New York: Japan Center for International Exchange, 2013, p. 215.

[13] Japan, Philippines strike broad accord on defense equipment Transfer. [Online]. Available: http://www.japantimes.co.jp/news/2015/11/20/national/politicsdiplomacy/japan-philippines-strike-broad-accord-defense-equipmenttransfer/\#.VnEFqVykTdk

[14] M. Pollmann. Amid South China Sea tensions, Japan strengthens ties with Philippines, Vietnam. [Online]. Available: http://thediplomat.com/2015/12/amid-south-china-sea-tensions-japanstrengthes-ties-with-philippines-vietnam/

[15] P. Parameswaran. Japan and Malaysia's new strategic partnership. [Online]. Available: http://thediplomat.com/2015/05/japan-andmalaysias-new-strategic-partnership/

[16] J. W. Hornung, "Japan's pushback of China," The Washington Quarterly, vol. 38, no. 1, pp. 167-183, Spring 2015.

[17] P. Parameswaran. Japan and Laos forge new strategic partnership. [Online]. Available: http://thediplomat.com/2015/03/japan-and-laosink-strategic-partnership/

[18] Japan's approach to Myanmar. [Online]. Available: http://www.japantimes.co.jp/opinion/2013/05/03/editorials/japansapproach-to-myanmar/\#.VnE_SlykTdk

[19] T. Watanabe. (November 2013). Why Myanmar matters: ensuring the future of the liberal international order in East Asia. [Online] Available: http://www.tokyofoundation.org/en/articles/2013/myanmar-matters

[20] C. Dalpino, "Japan-Southeast Asia relations: Abe opens new fronts," Comparative Connection, A Triannual E-Journal on East Asian Bilateral Relations, May 2015.

[21] T. Fukuda, "Japan's new ASEAN diplomacy? why the Abe doctrine may be counterproductive," Jiji Hyoron, pp. 23-29.

[22] P. Kung. Cambodia-Japan Relations: Beyond the East China Sea. [Online]. Available: http://thediplomat.com/2015/02/cambodia-japanrelations-beyond-the-east-china-sea/

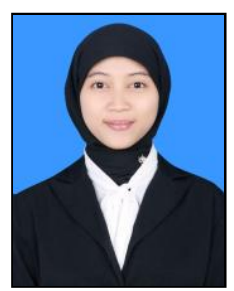

Mahar Nirmala was born in Yogyakarta, Indonesia, in October 1991. She obtained her bachelor of arts in political science at the Department of International Relations, Faculty of Social and Political Sciences, Gadjah Mada University, Yogyakarta, Indonesia in November 2013. During her study, she worked as a lecturer assistant for "Japan's Foreign Policy," "Diplomacy in East Asia," and "International Relations in Southeast Asia" while working as a part time research assistant in Institute of International Studies, Gadjah Mada University. During 2012-2013, she was an exchange student at the Department of International Relations and Political Science, Seoul National University, South Korea and Department of Education, Nagoya University, Japan. She is currently a candidate for the degree of master of international studies at the Graduate School of International Studies, Seoul National University, under the support of the Indonesia Endowment Fund for Education. 